\title{
DEVELOPMENT ECONOMICS OF DEFENCE IN CZECHOSLOVAKIA AND THE CZECH REPUBLIC 1950-2015 IN COMPARISON WITH THE ECONOMICS OF DEFENCE IN DEVELOPED COUNTRIES.
}

Prof. M.A. Miroslav KRČ, CSc.

University of Defence, Brno, Czech Republic.

\begin{abstract}
The article describes the development of the economics of defence in Czechoslovakia and the Czech Republic between the Marxist paradigm background and the concept of defence economics in developed countries. New research and development was carried out after the collapse of bipolarity. It shows the close cooperation between Czech and Polish economists. After 2007, attention is focused on examining the microeconomic aspects of defence and defence policy as part of economic policy and the role of military peacekeeping missions in national economic policy and the position and role of Armed Forces' foreign missions in national economic policy.
\end{abstract}

Keywords: defence, German military economics, economics of national defence, military economics, Stankiewicz, national defence economics, economics of defence and security.

\section{Introduction}

If you work in the defence sector, particularly in business development, sales or marketing, and wish to enhance your knowledge and skills, then this course should be relevant to you. The global post-war defence economy is characterised by both rapidly escalating research, technology and acquisition expenditure and taut, 
if not declining, defence budgets. These twin pressures have forced policy-makers to focus on achieving the goal of "affordability" through value-for-money initiatives. However, efficient management of scarce defence resources at the „Departmental" level is not undertaken in isolation from broader economic influences. Thus, in the contemporary study of defence economics, it is essential to examine the contributions that defence-industrial strategy, technological advancement and competitive and cooperative structures have made, and are continuing to make in the shaping of the 21 st century global eco-system ${ }^{1}$.

\section{Fundamental definitions of defence economics}

A consensus exists among experts on defence economics in understanding the defence economy to be an individual branch of study. According to economists of defence - such as American experts Hitch and Mc Kean - the problems of national defence are economic problems. Ch. Hitch and R. McKean (1960) see the main objective of the work of economists of defence as assisting the decisionmaking bodies, their advisers and generally all concerned citizens by presenting how economic analysis can be helpful when selecting the appropriate (efficient and economic) political procedures and actions. The aspect of economic-efficient allocation and exploitation of resources ${ }^{2}$ appears as one of the most important aspects of military problems. Here it is necessary to mention that these problems have been studied in the essay, The Theory of Games and Economical Behavior, published in the USA in 1944. Since 1965, the hitherto analysis of the armed forces system became an analysis of systems for the entire armed forces.

In 1975, the British economist, G. Kennedy, began the first of his texts on defence economics with a passage describing the "application of economics in defence

1 Details: Czech Persective of thedevelopment of Defence Economy, Military Economy Developded in Industrial Countries, andMilitary Economy Within the MarxistParadigm1950- 2010. Ekonmický čaopis, No. 6, 2002. Was extended to new problems that deal with defense economy after 2001, and also responds to this discipline on the issue of lack of financial resources for defense after 2008.

2 Hitch, Ch. J., McKean, R.N.: The Economics of Defense in the Nuclear Age. New York 1960, cited according to publication 1986, p. V. 
issues"3. According to H. Kanter (1984), the economics of defence are an application of economical skills in all defense issues".

American economist dealing with economics of national security L. Olvey (1984) from the West Point (USA), together with his colleagues has stated in their outstanding work solving problems of economics of national security that "the essential part of research in the field of economics of defence is just the application of fundamental economic terms in issues of national security “5.

The British author, K. Hartley (1991), involves all the aspects of economy of defence and processes of disarmament and peace in the economy of defence (economics of defence). The economics of defence apply economic theory to the sector of defence in a broad sense ${ }^{6}$.

In the scientific task, "Concept of the Branch of Study and Proposal of the Postgraduate Study „Economy of State Defence“ (1994) a team of authors from the Military College of land Forces in Vyškov states that "as a branch of study, the economics of defence describes military-economic relations and contexts of the process of economic support of defence in all its main phases and spheres - in the conditions of a market economy - especially in the area of production, allocation and utilisation of economic resources for the support of military needs in peace time, in the process of economic mobilisation, the deployment of a war economy and also the provision of the needs of defence by means of combat operations ${ }^{\text {“7 }}$.

An outstanding Polish economist dealing with defence economics, Professor W. Stankiewicz (1994)from the National Defence Academy in Warsaw, discusses that "the subject of the research work within the economics of defence is the defence economy in its various types accordant with that part of the national economy

3 Kennedy, G.: The Economics of Defense. London 1975. p. 17.

4 Kanter, H.: Defense Economics 1776 to 1983 in Armed Forces and Society, 10. No. 3, Spring 1984, p. 427.

5 Olvey, L. D., Golden, J. R., Kelly, R.C.: The Economics of National Security. New York 1984. p. 8-9.

6 Hartley, K.: The Economics of Defense Policy. London 1991, p. 8, 9.

7 Concept of the Branch of Study and Proposal of Postgraduate Study of Economics of State Defense. Vyškov 1994, p.14-15. 
which satisfies the needs of the state defence system both in peace time and in a time of jeopardy or war8.

In the introductory chapter of the publication entitled "Handbook of Defense Economics" from 1995, the American professor, T. Sandler, and the British professor, K. Hartley (1995), define defence economics as follows: The economics of defence enquires into issues of allocation of resources, distribution of revenue, economic growth and stabilisation applied to state security. It also includes a study of impacts of defence expenditure - both from the domestic and also external perspective - on macroeconomic variables such as the employment rate, production and growth. The economics of defence also has its microeconomic dimension which is implied in the analyses of industrial basis, programme of cooperation, offset, evaluation of military contracts and military acquisition. Defence economics applies theoretic economic instruments in the study of defence and related issues, including disarmament and peace ${ }^{9}$.

The Slovak economist, L. Lašček, from the Military Academy in Liptovský Mikuláš (Slovak Rep.), who deals with economics of defence, defines this discipline in the following way: "The economics of state defence is the science of economic provision for the defence needs of the state." ${ }^{10}$

The Czech economist, prof. Krč from University of Defence in Brno (Czech rep.) in his publication (2001) „Brief History of Defence Economics”11 defines defence economics as a branch of science seeking economic regularities that influence national security and its subject is that sphere of the national economy which satisfies the needs of the state defence system with respect to potential stages of a crisis and jeopardy of state security, including a war conflict. It includes all the aspects of security economics and of the process of disarmament and peace. On the basis of the development of scientific research, prof. Krč (2014) defines defence economics as: the application of economic instruments on defence problems, both from a macroeconomic and from a microeconomic perspective.

8 Stankiewicz, W.: Ekonomika obrony. "Defense Economics" Warszaw 1994, p. 19.

9 Handbook of Defense Economics. New York 1995, p. 3- 4.

10 Lašček, L. Ekonomické zabezpečenie obrany štátu. In: Spoločnost', armáda, osobnosṫ.( The economic state defense. In: The company, army, personality) Trenčín, SamO 1, 1999.

11 Krč, M.: Nástin dějin ekonomiky obrany. „Brief History of Defence Economics”. Praha 2001, p. 191. 


\section{Research areas of defence economics}

According to facts mentioned above, it is possible to conclude that the definition of defence economics is very broad. The following possible definition is a synthesis of preceding definitions and the subject of then study of defence economics can be that part of national economy that satisfies the needs of the state defence system with regard to potential stages of a crisis and jeopardy of state security, including a war conflict. It also includes all the aspects of security economics and of the processes of disarmament and peace. The problems of war and peace time economy, arms races and agreements on armament control; economic impacts of defence expenditure on economic development, industrial platform, armament acquisition policy, arms trade, military alliance and sharing the defence burden, economic war and terrorism, disarmament and conversion may serve as examples. This topical range can include further areas such as budgeting, the defence production function, incentive system and performance indicators, issues of training, option between professional army and forces based on general conscription; substitution possibilities, research on internal markets within the armed forces and various forms of organisations and their functioning etc.

Defence economics applies economic theory to the sector of defence in a broad sense. It includes the defence department, departments participating in economic provision of defence, armed forces, and defence industry, with its direct or indirect impact on the domestic or international environment.

Economic problems of the defence provision consist in the selection of the appropriate strategy, technology and forces structure by means of which it will be possible to execute the defence policy objectives at the lowest possible costs with respect to limited resources. It is necessary for politicians and also for the armed forces to make their decisions on these issues under budget pressures and with respect to given objectives. So, the subjects of the decision-making will face the consequence of their decisions in the form of costs. However, to be able to achieve the target, it is necessary for all decision/making bodies to perform economic analysis on all levels. 
The complex of economic topics related to defence issues examined since the end of the World War Two in advanced industrial countries is very extensive. A partial list of these issues could include the following topics ${ }^{12}$ :

- Deterrence, war prevention, launching and termination of a conflict.

- Strategic interactions, arms race, armament control.

- Alliance formations, resource allocation and behaviour.

- Macroeconomic interactions in a time of war, peace, disarmament and conversion.

- Comparison between the controlled and market economy from the point of view of defence resources.

- Mobilisation, post-war restoration.

- Optimisation and effectiveness of forces level and structure.

- Exploitation of the labour force capital: manpower, conscription and voluntarism.

- Military preparedness, strategic materials and policy of defence industry.

- Analysis of supply, acquisition and defence contracts.

- Commercial dependence, export control, trade sanctions and economic warfare.

- Foreign aid, developing economies and defence in countries of the third world.

- War economy and economic mobilisation.

- Impact of military expenditures on macroeconomic and microeconomic development.

After World War Two, research of defence economics in advanced industrial countries, with its wide empiric basis, has developed rather favourably. At this time, defence included many protective and aggressive activities undertaken by nations and their governments in order to specify, facilitate and preserve their interests in the tangle of other nations. Defence economics must have included the impact of scarcity of resources on the determination of limits for such aggressive or protective activities and also their production. As nations act within the international system of other states and a number of non-governmental actors, the economics of defence have to include interactions between various national states

12 Handbook of Defense Economics. New York 1995, p. 15. 
that have always struggled for their security in wider regional and international economies.

The abandonment of historicism in economics - necessary and occasionally altered for the requirements of that time - resulted partly in a precise analysis of actual war costs and their political and social implications and also in an analysis of the cold war costs. However, an applicable theory of the economic growth was developed first in the 1950s and 1960s - and was afflicted with something pathetically powerless because the growth-theoretic and growth-political problems of insufficient resources should have been solved, in the best case it would have been a comparative static analysis. Nevertheless, the whole post-war era has been influenced by a number of case studies, which have consequently served as a basis not only for decisions at top political levels but, at the same time, as an important instrument for an abstraction of theoretic conclusions on the basis of an analysed empiricism. The necessity for defence theory to perform studies ex-post with an abstraction of conclusions ex-ante has been approved. Many intellectual instruments dealing with conditions of "mixed economy" - with the relationship between the private and public sector in the economy - figure in economic discussions. The cost-utility analysis, Pareto optimum and Pareto efficiency, the opportunity costs theory and also the theory and praxis of social indicators in the armed forces belong to this area. As a subject it is a continuation of the works of Adam Smith, although with different terms and indications. Military expenditure is not considered just as financial expenditure of the state but also its morphological and structural effects are discussed in connection with national economic events.

New branches of science arise that deal with the military phenomenon: military sociology, investigation of peace and conflicts, part of the research of aggression in social psychology, political science as political sociology which understands e.g. the amount and structure of the expenditure of a state or of certain defence alliance that is as a result of intentional political decisions inside a real or just assumed "military-industrial complex", while earlier economics inclined to understand it just as a theory of certain given "data". In defence economics itself besides an ongoing significant inclination towards statistics and analyses of the state (policy), there is also a stronger connection with the growth theory than ever before: military expenditure is discussed as one of the instruments within the Harrod 
models, whereas the pivotal element is the phenomenon of military technological progress, its pioneer role - similar to the one in the J. A.Schumpeter essays - and the distribution of its usefulness to various sectors inside the economy.

Now, we can try to formulate a brief summary of our treatise of defence economics in advanced industrial countries after World War Two. From the point of view of the external form, many publications are available, above all those pertaining to Anglo-Saxon literature. Besides a number of hardly comparable monographs, a trend towards "case studies" is evident. The case studies represent a result of the scientific division of labour.

Defence economics is directly related - more than in the past decades - to other new sciences, e.g. politics and sociology (which includes the analysis of the military-industrial complex), social psychology, and various socio-critical schools. The historical dimension of defence expenditure - once often missed out - can help to establish a new "scale" for future theoretic model analyses. An analysis of individual elements of the war-economic potential and issues of the implementation of the military power forms premises for the study of defence economy in the industrial sector.

The dynamics of the thinking in the field of defence economics have assisted in getting over the rigid boundaries of traditional economic literary events and to increase the value of scientific consultations.

In the initial period of the cold war, along with the intensification of problems of the national security of the USA and further during the cold war, the policy requirements changed from issues of how to win an armed conflict to issues of how to gain superiority in a lengthy conflict. Defence economics has developed in several directions under these conditions. On the microeconomic level, the operations research has led to the development of the cost-effectiveness analysis and the cost-utility analysis. Thus, the conception that governments - by efficient use of the economy as a non-military instrument - could influence or support various sorts of strategic goals has become a doctrine of national security. The idea that the economy itself is an instrument of defence policy, whereas economic principles are determinant for an effective arrangement and application of such instruments, was developed in this period. 
Considering that the armed forces utilise manpower intensively, the main problems to solve have been: impacts of recruitment on the economy, budgetary vs. actual economic costs of general conscription, consequences of general conscription for individuals, a comparison of the pension system and a system stimulating further service of volunteers.

Issues of the acquisition process represented an important area. Questions relating to economic mobilisation, the transition of the production of strategic supplies and the preservation of the production base and the dependence on foreign suppliers were investigated. Furthermore, we can find essays on types of weapons systems required within an escalating international conflict. Economics has helped to clarify this issue by applying the ideas of the production theory in the field of defence provision ${ }^{13}$. Thus the study of an efficient utilisation of the capital and manpower condition of organisational structures of forces in larger countries, as well as studies comparing weapons for several deployments and weapons of one possible deployment, studies comparing reliability and replaceability and issues related to the term "logistics".

\section{Military economics in Germany}

When trying to define defence economics in its German interpretation, it is necessary to mention two assumptions to preserve objectivity: the first regards finishing with the results of "Wehrwirtschaftslehre" from the days of Nazism, the second is the pressure of Anglo-Saxon economics.

Intellectual efforts have been considerably concentrated on microeconomics, a problem which has been reflected in the development of original military economics entitled, Theory of Economic Serviceability of Troops (Betriebswirtschaftslehre der Streitkräfte). Later, a new term - Military Economics/Militärökonomie) was used.

German military economics incorporates both the elements of public economics and the elements of business economics. Its fundaments are very complex tho-

13 Handbook for Defense Economics. New York 1995, p. 28-29. 
ugh it is based on traditions of German thinking related to the economy. Military economics is a dogma of economics in military matters. The economy inside the military itself plus overall economic connections represents military economics.

The economic provision of military actions and responses is crucial in the studies of G. Kirchhoff $(1986)^{14}$. German theoreticians representing military economics aimed their attention at microeconomic issues of the armed forces behaviour ${ }^{15}$. This was oriented from the very beginning towards a discussion of the interior business problems of the armed forces. Mainly these are the tactical-economic deployment of forces, costs and calculations of effectiveness of the armed forces action, economically efficient organisation and organisational flexibility, and the theory of economic decisions in conditions of a military organisation belong to these interior business problems.

According to German authors, military economics is an inter-disciplinary science in the group of economic sciences. The army is the object of research for disciplines of economic sciences and for further special economically oriented disciplines like the history of military economy, the psychology of military economy, the pedagogy of military economy, the economics of military education and military economic geography. We can presume that such a summary of macroeconomic and microeconomic facts and issues in the military - and in connection with cognition - is meaningful because a comprehensive opinion can be derived from a rational reduction.

The theory of military economics emphasises that, nowadays, it can be important for the military to define economic science as a scientific cognitive object.

While refusing the category of defence economics, German authors emphasise that military economics also means an economic examination of military goals from the overall economic point of view and, thus, from the macroeconomic point of view.

14 An outstanding German expert of military economics, vice chairman of the Association of Military Economics in the Federal Republic of Germany, research worker of the Research Institute of Military Economics .

15 Kirchhoff, G.: Handbuch zür Ökonomie der Verteidigunspolitik. Regensburg 1986, s. 534 . 
Organisational structures and internal business dynamic processes are interesting for military-economic research.

In the Federal Republic of Germany, military economics has been essentially based on the Bundeswehr's economic behaviour (armed forces including Bundeswehr management) and parallels between the science of the business economy and the armed forces.

The Bundeswehr expresses its connection with business economic thinking by acting in public as an economic business which has to - because of permanent reduction of its funding - start to think economically and by the fact that about one quarter of graduates from colleges of the Bundeswehr have been educated as business economists. At the present time, the percentage of military expenditure on GDP comes - in Germany's case - merely to 1.5 \% (2014).

Primarily, the research work of J. Gerbera ${ }^{16}$ from the 1960 s is used to consider the armed forces as an economic business. Gerber has stated in one of his many articles: "The armed forces are bodies which a nation or several nations have established to ensure their vital order. So, the armed forces represent a special type of enterprise that we understand according to the purpose of their deployment". Every enterprise may be divided into four basic elements which will be further indivisible: property (in armed forces armament and equipment), capital, manpower, organisation. At the same time, the organisation serves for a combination of the remaining three elements that should perform their basic functions. "According to their mission, the armed forces should belong to the enterprises of services because their task is to prepare and be ready for defence ${ }^{\text {"17. }}$.

An innovative and, to a great extent, revealing essay by J. Gerber, "Introduction of Principles of Rational and Economic Thinking in the Armed Forces" - works with a system of axioms from which the propositions are derived where spatial linkages of our world are formed satisfactorily. "The armed forces can be understood as the oldest big business, they are the oldest place for institutional operationally-

16 Retired major general, titular chairman of the Association of Military Economics, founder of the scientific discipline logistics in the Bundeswehr (1962).

17 Krč, M. a kol. Německá vojenská ekonomika. (The German military economy) Tribun: Brno, 2010,pp. 84-85. 
economic actions and commanders of troops have been, are and always will be economic administrators ${ }^{\text {“18. }}$.

It is necessary for all areas, all activities and for every situation of the armed forces to perform a cost-utility analysis; however, no military commander can be just an economist. Nowadays, the science of the operating the economy has been fully integrated into institutions of the Bundeswehr, and courses studying operationaleconomic issues at academies and universities of the Bundeswehr exist too. An increasing number of economically educated personnel are active in the sphere of logistics, planning, costs calculation, organisation and armament planning ${ }^{19}$.

\section{The defence-economic thinking within the Marxist paradigm, including Czechoslovakia}

That type of thinking developed under the influence of the analysis of the Soviet war economy and the difficulties that the Soviet Union encountered at the beginning of the war $^{20}$. That is also why much attention was devoted to the issues of war economy. Another powerful factor influencing the investigation of war economy was ideology and the communist party propaganda. The excessive emphasis on the normative aspects of the inquiry was very often combined with apology. War economics was understood as a scientific discipline dealing with economic problems from the point of view of war $^{21}$. This problem is described in the publication „Brief History of Defence Economics” (2001).

The discipline sought to formulate the principles of implementing various models of war economy and to discover the laws governing their behaviour. There

18 Krč, M. a kol. Německá vojenská ekonomika. (The German military economy) Tribun: Brno, 2010,pp. 83.

19 Krč, M. a kol. Německá vojenska ekonomika. (The German military economy) Tribun: Brno, 2010,pp. 162 - 174.

20 Voprosy v ekonomike sovremennoj vojně. Moskava 1951; Lagovskij, A.N.: Strategija i ekonomika. Moskva 1957; Vozněsenski, A.A.: Válečné hospodářství SSSR za velké vlastenecké války.( War economy of the USSR as of the Great Patriotic Wa)r Praha 1949.

21 Krč, M.: Nástin dějin ekonomiky obrany.(Brief History of Defence Economics). Praha 2001, p. 156. 
were two basic trends in war economics with respect to its research orientation: (1) a wide category of problems ranging from the question of the state (coalition) potential to the question of war requirements; and (2) principles of the implementation of war economy systems and the laws of their functioning. At the same time, war economics examined the general economic problems in connection with war. The first group of problems included such research topics as peacetime preparation for war economy, military-economic potential, economic potential, economic mobilisation, war reproduction, distribution of supplies in various models of war economy, etc. Among the problems in the second group were: principles of stocks creation, alternative ways of the transition of industry to war production, principles of rational regulation of consumption, methods of dealing with lack of skilled manpower, transition of agricultural production to war production, etc.

War economics addressed the problems bearing on war both in peacetime and in wartime. This was justified by the assumption that many of the processes of adapting the economy to the needs of war were of a long-term nature and could not, therefore, be properly addressed only shortly before the outbreak of the war conflict. The nature of many of these problems required, according to the doctrine of war economics, that they be addressed already during peacetime. Among such issues were, to give just a couple of examples, local defence problems and matters connected with transport and infrastructure. War economics had an interdisciplinary character ${ }^{22}$. The huge economic war burden, the changed conditions of economic life, the growing role of the state, unnatural relationships in areas of production and distribution, all these led to considerable deformations in the functioning of the economic laws that were transformed into sorts of hybrids that, because of their stochastic character, were very difficult to predict. This situation, combined with fears of new problems yet unknown in the area, tainted the expectations of the researchers at that time. Neither political economy, nor other economic sciences investigating peacetime economy, were able to address successfully the above described problems, and thus the attention of many researchers turned to war economics.

22 Krč, M.: Nástin dějin ekonomiky obrany.(Brief History of Defence Economics). Praha 2001, p. 157. 
Different models of defence economy could not be governed by the same laws, since their scope was limited by historically variable conditions. With changing socio-historical conditions, the manifestation of some of the laws was in various ways distorted, other laws ceased to operate at all and, at the same time, entirely new laws, characteristic of war economy, emerged. With its subject matter, war economics overlapped with many affiliated disciplines, for example with the so called sector economic sciences - especially economics of industry, agriculture, transport, trade and international economic relations. The economics of international relations was used to formulate theses and propositions that were then applied in economic processes within the socialist military coalition. In addition to that, military economics had many points of contact with the so called military science, especially with the military strategy and the armed forces economics. It used general research methods to analyse war related problems of industry, including the arms and defence industry.

The basic method of research in war economics was the method of dialectical and historical materialism. That method allowed war economics to put the studied phenomena in evolutionary context and to take account of their qualitative changes. It also made it possible to view phenomena from varying perspectives given by dialectical opposites such as diachrony - synchrony, whole - part, static - dynamic, praxis - theory. Among the main research methods of war economics was economic analysis ${ }^{23}$. That analysis enabled the researchers to investigate the relationships and mutual influence between various economic processes and phenomena. Depending on the character of the problems studied, the researchers preferred dynamic or static analysis. Static analysis enabled them to reconstruct a picture of the investigated phenomenon (for example, the size of stocks in the whole country) at a particular point in time. Dynamic analysis, on the other hand, allowed them to follow the evolutionary trajectory of the phenomenon in time and to uncover its causes. War economics often used statistical research methods. Another research tool that was introduced into the methodological arsenal of war economics was the systems method. Because of the important role played in war economics by past experience, it also made use of the historical method. The knowledge and understanding of the past and present status of the investigated

23 Krč, M.: Nástin dějin ekonomiky obrany. (Brief History of Defence Economics). Praha 2001, p. 158. 
systems formed a basis for theoretical generalisation and enabled the researchers to make prediction. The prognostic function of war economics was regarded as very important from a practical point of view.

War economics worked out or took over from other disciplines and adapted for its own purposes many theoretical concepts and categories that were generalisations of economic phenomena and processes. The most important categories of war economics included the concept of war-economic potential which was used to express the connection between the military power and the economic possibilities of the state. The full understanding of that concept presupposed an acquaintance with a number of other concepts of war economics such as military power, arms production, potential stocks, etc. Another important category of war economics was the concept of economic mobilisation. The definition of that concept referred back to such auxiliary concepts as material stocks, war deployment, transfiguration, etc.

War economics also used many concepts that had already been in use in other disciplines. War economics very often appropriated them by adjoining suitable adjectives to them, turning them thereby into more specific concepts. To give just a few examples, one can name such concepts as strategic raw materials, war potential of war labour, or war social production. There were also many concepts (e.g. allocation, stocks, conversion) that, after they had been taken over by war economics from other disciplines, retained their old names unchanged while changing slightly their meanings in adaptation to the specific conceptual environment of war economics.

War-economic potential was defined as the capability of the economy of the state (coalition) to provide products and services during economic mobilisation and war. It was closely linked to the concept of social production force used in political economy, which referred to the production potential of the society. Even though the two concepts were closely linked, they were not identical. The differences between them mainly reflected the differences between the war aim and the peace aim of the economy. The economic transition associated with the change of the aim of the economy from peace to war was so radical that many authors spoke of a transformation of the whole economy from peace economy to war economy. 


\section{Research areas of Czech defence economics after the collapse of bipolarity 1989-2015}

The development of the economy of defence in Czechoslovakia - influenced the Polish concept of economy of defence for ages. After 1989, as a result of close cooperation and under the auspices of prof. Stankiewicz, economy of defence was developed, as was also the parallel solution Defence Economics in Poland and the Czech Republic designed primarily at the Military Academy Brno. In the Czech Republic, this branch of science was called defence economics. In the new study programme (2014) it is called economy of defence and security. The economics of defence research in the current conditions of the Czech armed forces should focus on the following topics relating to the issue of the efficient resource use:

- How to introduce economic accounts as a means of control into the armed forces.

- How to make use of flexible accounting on all levels of command.

- How to apply the operational analysis for multi-criterial decision-making in the activities of the military professional.

- Carrying out of a comparative-descriptive study of the use of the cost-benefit analysis in the armed forces sector.

- Theoretical preparation of the operational economic research into the costs of military activities in the sector of the armed forces.

- Investigation of mutual relations between costs and benefits.

- Theoretical definition of the cost-benefit analysis in the military sector.

- Analysis of cost effectiveness in the sector of defence.

- Theoretical clarification of the analysis of cost effectiveness and utility.

- Controlling as a means for ensuring the economic use of resources in the armed forces.

\section{Syllabus economics of defence and security, University of Defence, Brno}

To give information about basic principles of functioning, structure and problem spots of the national economy, which partly creates conditions for basic satisfying of societal needs as a protection of territorial integrity, state institutions, citizens and property is the main aim of the subject. Students 
familiarise themselves with the main study items of security and defence economics. A description of the study area starts from determination of basic terms and categories such as defence, security, military expenditure, the defence industrial base to forecast the present and future development of the economic securing of defence and protection within changed economicsecurity conditions.

The theme is divided into several connected topic blocks. It provides the best understanding of the mutual connection between economy, defence and state security.

The first block provides basic information for successful study and understanding of the defence and security economy. Special attention is devoted to the importance of delimitation within the public sector area (related to economic provision, defence requirements and political decision-making process) and an explanation of the usefulness and economic parameters of defence and security for society and the individual.

In the second block, attention is devoted to specification, classification and economic consequences of military expenditures.

The third block introduces students to defence economy, arms production and the arms trade points at issue. At the same time, the importance of the defence industrial base for securing national defence and economic development is explained (technological advancement, informational society and innovations).

The economic consequences of allied national defence and security provision are described and explained. The economic and military costs and benefits of military alliance are discussed too.

Within the fifth and sixth block economic aspects of armed conflicts are discussed. The causes, impacts and economic consequences of armed conflicts arising and their conduct nowadays (civil war, regional armed conflict, terrorism) is explained to students.

The final seventh block deals with of the outlook for future development of the defence and security economy and economics in connection with emerging risks, threats and challenges within this area. 
Within the topic, we have to focus on:

- Introduction to defence and security economics Economic aspects of defence and security provision

- Military expenditure - its importance and classification

- Economic impacts of military and security expenditure

- Defence industrial base, its importance, structure and financing

- Arms trade as economic driver of securing defence

- Military alliance and international cooperation in defence and security

- Economics of armed conflict Economic aspects of international terrorism

- Future development of economics of defence and security - Economic aspects of defence and security privatisation (Economics of private military and security companies)

- Future development of economics of defence and security - Economic reasons for structural changes of armed forces and using them (Economics of military robotics)

- Future development of economics of defence and security Economic efficiency under conditions of defence and security

The research into the above topics should contribute to the realisation of the requirement that the armed forces should be approached as an economic enterprise and their management should respect the principle of economics. Flexible accounting is a necessary condition for the introduction of business economics and its criteria into the armed forces. The assignment of the responsibility for a costbenefit relationship should promote more efficient use of resources in the armed forces. It should help the armed forces to perform in conditions of decreasing resources and assuming responsibilities for new tasks. The cost-performance projects should confirm the possibility of applying the principles of economic management in the military system. Special attention should be given to potential areas of conflict with other systems such as the system of personnel control, military rules of conduct, respect for military hierarchy etc. It is necessary to find the means of coping with the systematic unpredictability of the military budget as account incomes and outlays. Further elimination of uneconomic behaviour will probably only be possible through even stronger pressure on the socio-economic system. The evaluation of behaviour from the point of view of the principle of economy should be incorporated into the carrier evaluation system. The quantification of military activities should lead to rational ways of meeting military 
objectives. A new generation of young scientists examines the microeconomic aspect of the armed forces; the emphasis is on the economic efficiency in the public sector - defence. The aim is to examine defence policy as part of economic policy. This is very well led by some developed countries, such as France.

\section{Example application of the defence economy in developed countries - FRANCE}

Applying economics to the defence sector raises many issues concerning more efficient use of defence resources and further analysis and management. This effort covers several areas, including human resources, investment (armaments), purchasing, export, outsourcing, regulation of the industrial sector and estate assets. The figures involved in defence economics are numerous and belong to diverse organisations such as the Ministry of Defence (including Defence Staff, Armaments Procurement Agency (DGA) and General Secretariat for Administration (SGA)), industry, consultancies and universities. Various methods based on proven management models are used, as well as statistical tools and a rigorous analytical economic framework.

\section{Purchasing policy}

- During the first council on modernising public policy on 12 December 2007, the government decided on vigorous action regarding purchasing in order to make the purchasing function more professional and reduce current purchasing expenses.

\section{Industrial policies}

- Reorganisation of the European defence industry is well underway. The Ministry of Defence is committed to it because it is part of a policy project to which France subscribes. France's strategy and effort in the defence industry are clearly committed to the building of a European defence and security space. 


\section{Economics/statistics}

- The monitoring centre for defence economics (OED) is part of the Financial Affairs division in the General Secretariat for Administration. It performs economic and statistical analysis on defence with the objective of managing and encouraging work in this area.

\section{Defence Economic Council}

- The Defence Economic Council organises dialogue between key figures with recognised powers: defence professionals, key individuals in France and abroad in business, economics, universities, the media and civil administrations as well as political and parliamentary representatives.

\section{Export}

- DGA leads and coordinates State support for armament exports. With its network of defence and armaments attachés, DGA provides business with knowledge of the international environment.

\section{Property policy}

- As a user of significant real estate holdings including special infrastructure, the Ministry of Defence has, for several years, implemented a property policy that fulfils the objectives of government policy: preparation of master plans, obsolete building inventory and property transfers.

\section{Czech Republic's entry into the European Union and the conduct of the defence market}

European nations are faced with major economic and financial problems requiring cuts in defence budgets. In addition, defence equipment is costly and costs are rising. Unit costs are also rising between each generation of equipment 


\section{Criteria for Defence Budget Cuts}

Economists approach defence budget cuts by starting from the fact that Armed Forces are subject to budget constraints. They do not have access to unlimited resources so that they are not immune from the standard economic problem of choices. There are some general economic principles for assessing the efficiency of defence spending. These include:

a. The principle of final outputs

All too often debates about defence budget cuts focus on inputs rather than final outputs. Typically, controversies surround cuts in the numbers of warships, infantry regiments, aircraft squadrons and the numbers of military personnel. This is the wrong focus: it addresses inputs. Instead, debates about defence budget cuts should focus on final outputs and the contribution of the various inputs to achieving different defence outputs. But immediately there is a major problem in that defence output is only defined broadly and vaguely in terms of peace, protection and security: there is a lack of any measure of the value of defence output. Traditionally, defence output was measured using inputs. More recent efforts to improve output measurement have used military capabilities; but capabilities lack a valuation so that no comparison can be made between the costs of defence and the valuation of its final output.

b. The principle of substitution

This means that there are alternative methods of achieving defence each with different costs. For example, in the private sector, competition and the search for profits leads firms to substitute cheaper methods of production for more expensive methods (e.g. machinery replacing labour). Applied to the Armed Forces, the substitution principle suggests that defence equipment might replace military personnel.

c. The principle of competition

Improved efficiency requires competition within both the Armed Forces and national defence industries. Faced with budget cuts, the Armed Forces are likely to resort to collusion offering 'token' cuts in their forces. Examples include cuts to support units and reserve forces. Instead, real competition between the Armed 
Forces would use major budget cuts to force them to compete for a limited budget by exposing the true costs and effectiveness of their front-line forces and their latest new equipment programmes. ${ }^{24}$

\section{Inefficient European Defence Markets}

European defence markets are dominated by inefficiency in both their Armed Forces and defence industries. Within the Armed Forces, there is duplication of forces, bases, training and support functions. Similar duplication exists within Europe's defence industries where the focus on nationalism leads to duplication of costly development programmes and small production runs for national markets. These are costly inefficiencies. Possible solutions include the sharing of costly military assets, role specialisation and the development of a European defence industrial base.

Cuts in defence budgets and rising equipment costs mean that Europe's defence industries are too large. Advocates of a European defence industrial base suggest the need for a more integrated defence industrial base achieved through industrial re-structuring, harmonisation of equipment needs, co-ordinated defence research, the protection of critical military technologies in Europe and an emphasis on security of supply. Such proposals resemble 'magic wand' economics. The rhetoric needs to be subject to careful and critical economic analysis.

\section{Conclusion}

On the basis of the study of development of defence economics and military economics, we have come to the conclusion that both these scientific disciplines are based on the application of economic instruments to the defence sector. The research work also shifts from the macroeconomic to microeconomic level in

24 http:// www. e-ir.info/2013/09/20european-defence-policy-an-economic-perspective /( cit 2014-04-15). 
the defence economics. The study of economic problems of defence provision is based on case studies. Development trends and tendencies and consequent recommendations for the practice of troops are analysed in these case studies. It is necessary to perform the cost-utility analysis in all areas, for all activities and for every situation of the armed forces. The development of defence economy within the pre-1990 Marxist paradigm did not create sufficient conditions for the efficient allocation of resources in sector of defence.

In contrast to the prevailing notions, defence economics is not about reducing expenditure or putting the crucial national security matters in the public domain. A formal definition is needed for the sake of understanding the subject. Though it has been defined in various ways, the core definition remains that of applying economic principle and tools to all issues of defence, disarmament and peace. In recent years, this definition has been modified to include issues like economics of war, conflict and non-conventional conflicts, namely, terrorism, civil wars, revolutions, insurrections.

The basic application of economics in defence arises from the fact that total national resources are scarce and defence eats away a sizeable portion from them, many a time crossing 1 per cent of our GDP, if SIPRI (Stockholm International Peace Research Institute) data is to be believed. Basic economics teaches us to make rational choices, in the form of efficient resource allocation, a principle equally applicable to both defence and non-defence matters. In other words, defence economics is about allocating resources in terms of "choosing right doctrines, equipment and techniques, and so on to get the most out of available resources". Economising resources may imply spending less on some things and more on others to make the efficient use of resources available which have a variety of uses and users.

The relevance of defence economics can be gauged from its numerous contributions that range from economics of arms races to disarmament to modelling terrorist behaviour. It is worth mentioning a few areas which are significant from the Indian context. The most pressing issue is demand for defence expenditure, as it elicits a great deal of debate on the right size of defence budget. For defence economics, the basic determinants of defence expenditure are the national income and the level of threat perception (both internal and external). Once these determinants are quantified and put into a time-series analysis it becomes easy to come to 
a figure which represents the country's total demand for military expenditure. The advantage of this estimation lies in its sensitivity to the changes of threat perception and national income as well as forecasting the future demand level.

\section{Bibliography}

ARMED FORCES AND SOCIETY, 10. No.3, Spring, 1984.

HAHN, O. Militärbetriebslehre: Betriebswirtschaftlehrer Streitkrafte. Berlin: Verlag Arno Spitz,1997.

HARTLEY, K. The Economics of Defense Policy.London. 1997.

HITCH, CH. J., MCKEAN, R.N. The Economics of Defense in the Nuclear Age. New York.1960.

HOLMAN, R. A KOL Dějiny ekonomického myšlení. Praha: Grada 2007.

KENNEDY, G. The Economics of Defense. London, 1975.

KIRCHHOFF, G Handbuch zür Ökonomie der Verteidigunspolitik. Regensburg, 1987.

KRČ, M. Dějiny ekonomiky obrany. Vybrané kapitoly. Brno: Vojenská akademie:.1997.

KRČ, M. Nástin dějin ekonomiky obrany. Praha : AVIS, 2001.

KRČ, M. a kol. Ekonomické aspekty outsourcingu v ozbrojených silách, Brno: MONIKA Promotion, s.r.o. 2012

KRČ, M. a kol. Německá vojenská ekonomika, Brno: TRIBUN EU s.r.o, 2010.

KRČ, M. Teoretická a metodologická východiska německé vojenské ekonomiky. Univerzita obrany: Brno, 2009

KRČ, M., KAMIŇSKI, T. ET AL. Ekonomika obrany. Systém obranného hospodářství. Brno: Vojenská akademie, 1996.

KRČ, M., ODEHNAL, L. ET AL. Ekonomika obrany státu. Vybrané kapitoly. Vojenská akademie : Brno. 1998.

LAŠČEK, L. Ekonomické zabezpečenie obrany štátu. In: Spoločnost', armáda, osobnosté. Trenčín, SamO 1/99.

Militärökonomische Blätter , No.8 - 9, 1991, 1991.

NEDBAL, J., KRČ, M., ŠTANCL, L. Ekonomické a vojenské aspekty globalizace světové ekonomiky. Brno: Univerzita obrany, 2009

OLEJNÍČEK, A., KUNC, S. Ekonomické ř́zení v podmínkách armády, Uherské Hradiště: L. V. PRINT, 2012

OLVEY, L. D., GOLDEN, J.R., KELLY, R. C. THE Economics of National Security. New York, 1984.

ŠTANCL, L. a kol. Základy teorie vojensko-ekonomické analýzy, Brno: MONIKA Promotion, s.r.o. 2012.

STANKIEWICZ, W. Ekonomika obrony. Warszawa : AON, 1994. 
Vojenské rozhledy, č. 1, 2012.

Vojenské rozhledy, č. 2, 2010.

Vojenské rozhledy, č. 2, 2013.

VODÁKOVÁ, J. a kol. Nástroje ekonomického řízení ve veřejném sektoru. Praha: Wolters Kluwer 2013.

www. e-ir.info/2013/09/20european-defence-policy-an-economic-perspective. 